\title{
Zaburzenia metabolizmu i funkcji enzymów metabolicznych a proces nowotworzenia
}

\author{
Elżbieta Sarnowska, Marcin Leszczyński, Ewelina Macech-Klicka, \\ Małgorzata Stachowiak, Janusz A. Siedlecki
}

\begin{abstract}
Dr Otto H. Warburg wykład 1966 Nobliści w Lindau, Niemcy „Rak, ponad wszystkie inne choroby ma niezliczoną ilość wtórnych przyczyn. Jednak nawet w przypadku raka istnieje tylko jedna główna przyczyna. Podsumowując w kilku słowach, główna przyczyną raka jest zastąpienie oddychania tlenowego w normalnych komórkach organizmu przez fermentację cukru..."
\end{abstract}

Wzrost i rozwój organizmu jest nieodłącznie związany z dostępnością składników odżywczych. W związku z tym wyewoluowały specyficzne mechanizmy pozwalające na koordynację tych procesów w zależności od dostępności pożywienia, co umożliwia organizmom przetrwanie w czasie głodu. Zmniejszenie zasobów energetycznych powoduje wydłużenie życia, natomiast nadmiar kalorii jest powiązany z otyłością i chorobami nowotworowymi. Na poziomie komórkowym prawidłowe, dzielące się komórki aktywują szlaki metaboliczne, umożliwiające akumulację masy i energii wykorzystywanych do syntezy DNA w celu reprodukcji. Natomiast komórki nowotworowe przeprogramowują w sposób, wydaje się, kontrolowany swój metabolizm, aby dzielić się i rozprzestrzeniać w sposób niekontrolowany. Pewne geny kodujące enzymy metaboliczne zostają wyłączone w komórkach nowotworowych, a inne ulegają zwiększonej ekspresji, powodując zmiany metaboliczne. Badania prowadzone w ostatnich latach pokazały, że niektóre enzymy procesu glikolizy, mające swoją główną funkcję w cytoplazmie, mają zdolność do przemieszczania się do jądra komórkowego, gdzie pełnią zupełnie inne niemetaboliczne funkcje, np. biorą udział w kontroli ekspresji genów. Dlatego poznanie wpływu metabolizmu na kontrolę ekspresji genów może być niezwykle istotne w zrozumieniu przyczyn nowotworzenia.

\section{Alterations in metabolism and metabolic enzyme function and carcinogenesis}

Dr Otto Warburg (Nobel in 1931) in his lecture on Lindau Nobel Laureates Meeting in 1966, Germany, stated: "Cancer, above all other diseases, has countless secondary causes... But, even for cancer, there is only one prime cause. To summarise in a few words, the prime cause of cancer is the replacement of the respiration of oxygen in normal body cells by a fermentation of sugar..."

Growth and development of organisms are strictly dependent from availability of nutrients. Evolved specific mechanisms controlling those processes can help organisms to survive starvation. Calorific restriction leads to longer life span, but the opposite, too many calories are associated with obesity and tumourigenesis. On a cellular level, normal dividing cells activate particular metabolic pathways to accumulate cell mass and energy for DNA synthesis required for reproduction. By contrast tumour cells reprogramme their metabolism, possibly in controlled way, for uncontrolled division and growth. Some genes encoding metabolic enzymes are inactivated while others exhibit increased expression, causing metabolic changes in tumour cells. Recent studies showed that certain glycolytic enzymes mainly active in cytoplasm may move from cytoplasm to the nucleus where they can play different, nonglycolytic functions 
e.g., control the gene expression. Therefore, to understand the influence of metabolism on gene expression can be crucial to discovering the causes of carcinogenesis.

NOWOTWORY J Oncol 2016; 66, 2: 151-159

Słowa kluczowe: metabolizm, glikoliza, glutaminoliza, cykl kwasów trójkarboksylowych, efekt Warburga

Key words: metabolism, glycolysis, glutaminolysis, TCA cycle, Warburg effect

\section{Metabolizm i efekt Warburga}

Prawidłowe, normalne komórki mają zdolność „wyczuwania" substancji odżywczych. W przypadku braku pożywienia włączane są mechanizmy zmniejszające syntezę makrocząsteczek i zużycie ATP (adezynotrójfosforan — nośnik energii), a aktywacji ulegają szlaki produkcji ATP. Powstające w wyniku przemian metabolicznych produkty uboczne mogą uszkadzać komórkę, indukując zmiany w materiale genetycznym. Prowadzi to do uszkodzenia mechanizmów regulujących prawidłowe działanie komórki, a w przypadkach, gdy zmiany mają onkogenny charakter, do śmierci lub transformacji nowotworowej. Metabolizm komórek nowotworowych różni się od metabolizmu prawidłowych, zdrowych komórek (ryc. 1).

Komórki nowotworowe do proliferacji wykorzystują w znacznie większym stopniu energię z glikolizy tlenowej, z kwasów tłuszczowych i glutaminolizy [1]. Te właśnie zjawiska zaobserwował na początku XX wieku Otto Warburg. Wykazał on, że w komórkach nowotworowych poziom glikolizy jest znacznie wyższy niż w komórkach zdrowych [2, 3].Ta zmiana, zwana dziśs „efektem Warburga”, jest świadectwem tego, że komórki nowotworowe preferują do wytwarzania potrzebnej do wzrostu energii glikolizę, a nie - jak to ma miejsce w komórkach prawidłowych - mitochondrialną fosforylację oksydacyjną (ryc. 1A). W niedotlenionych zdrowych komórkach, np. mięśniowych, ma miejsce przekształcenie glukozy do mleczanu (ryc. 1B). Podobna sytuacja występuje w komórkach nowotworowych pomimo dostępności tlenu, który w normalnych warunkach hamuje glikolizę w procesie zwanym „efektem Pasteura" (ryc. 1C) [4].

Dane z literatury pozwalają powiązać, efekt Wartburga", czyli trwałą glikolizę tlenową w komórkach nowotworowych, z metabolicznym uszkodzeniem materiału genetycznego, czyli z aktywacją onkogenów i utratą funkcji produktów genów supresorowych $[1,3,5,6]$. Jednakże sam „efekt Warburga" nie wyjaśnia, w jaki sposób glikoliza tlenowa powoduje akumulację masy i nadmierną proliferację komórek nowotworowych. Glukoza nie dostarcza bowiem wszystkich niezbędnych składników potrzebnych rosnącym komórkom. Oprócz węgla, tlenu i wodoru do budowy elementów komórki potrzebne są jeszcze inne składniki, takie jak azot, siarka i fosfor. Rosnący nowotwór jest więc wielokomórkową masą, której brak wystarczającej ilości składników odżywczych i tlenu. To z kolei indukuje powstanie i wzrost nowych naczyń krwionośnych. Powstająca w obrębie guza nowa sieć naczyń jest niedoskonała i mało efektywna, co powoduje

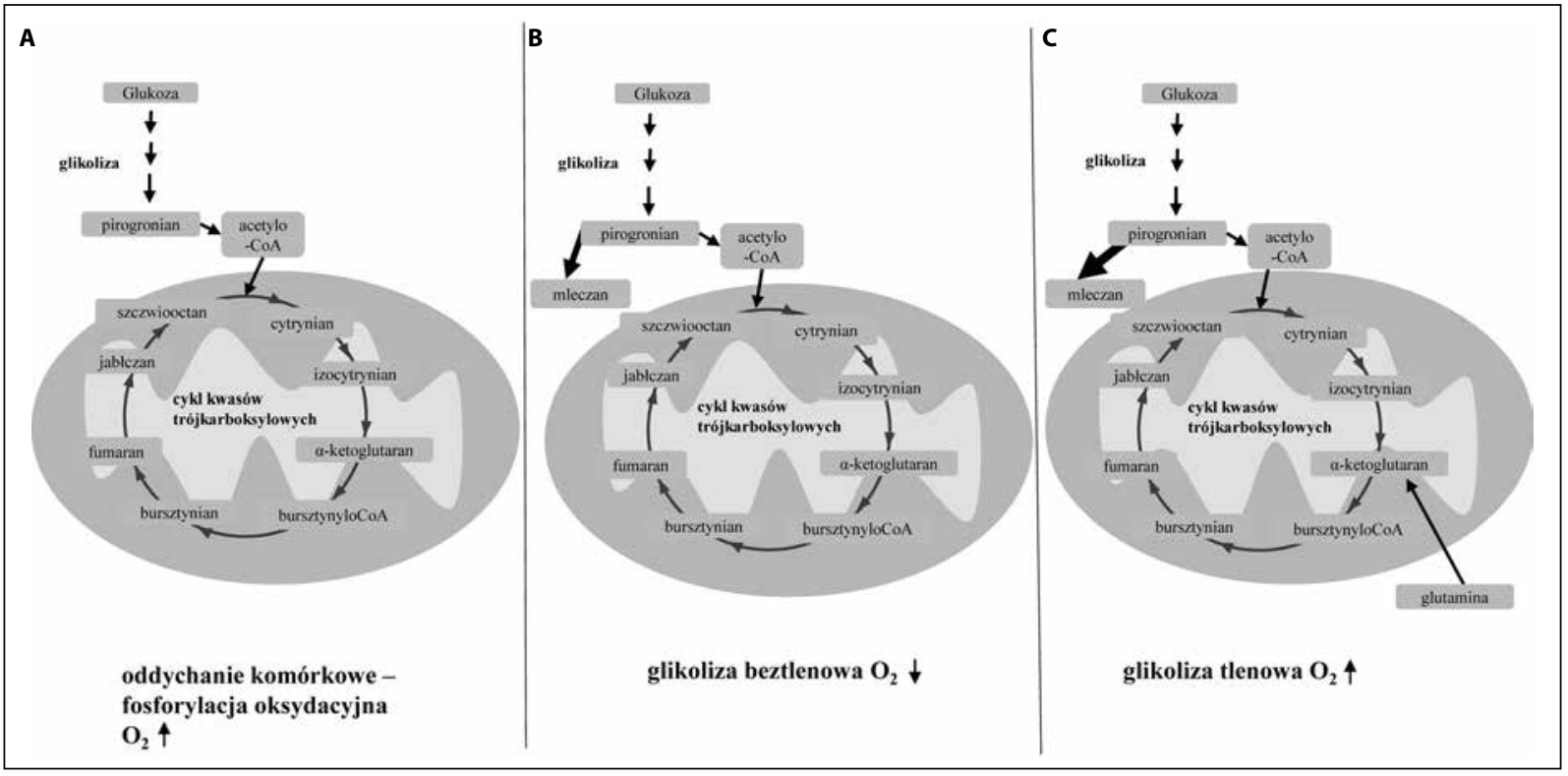

Rycina 1. Metabolizm w normalnej komórce (A), metabolizm w komórce w stanie niedotlenienia (B), metabolizm w komórce nowotworowej (C) 
brak substancji odżywczych i niedotlenienie - hipoksję [7-9]. Dlatego adaptacja do takich warunków jest niezbędna do przeżycia i wzrostu nowotworu. Przełączenie metabolizmu („efekt Warburga”) ma za zadanie zaspokojenie potrzeb energetycznych/budulcowych dla szybko proliferujących komórek guza. Oprócz zmian metabolicznych napędzających proliferację i proces kancerogenezy w samej komórce zaobserwowano również zmiany na poziomie metabolizmu w całym organizmie. Uwalniany do krwioobiegu z szybko proliferujacych komórek nowotworowych mleczan jest przekształcany w wątrobie w tzw. cyklu Cori do glukozy [1]. Jedna z teorii mówi, że mleczan może być wykorzystywany przez tkanki całego organizmu jako paliwo przy braku glukozy, jak również może być cząsteczką sygnałową powodującą stabilizację czynnika HIF-1 (Hipoxy Induced Factor) i angiogenezę [10]. Wzrost poziomu dehydrogenazy mleczanowej (LDH) we krwi jest złym czynnikiem rokowniczym i obserwowano go u pacjentów z zaawansowanym niedrobnokomórkowym rakiem płuc, czerniakiem, rakiem nerki i innymi nowotworami [11].

Przyczyna rezygnacji z oddychania mitochondrialnego na korzyść glikolizy tlenowej w komórce nowotworowej wciąż jest nieznana. Produkcja ATP z cząsteczki glukozy w przypadku mitochondrialnej fosforylacji oksydacyjnej wynosi 36 cząsteczek ATP, a w glikolizie tylko 2. Wydaje się jednak, że glikoliza jest znacznie efektywniejsza, gdyż produkcja ATP tą drogą jest szybsza niż w fosforylacji oksydacyjnej, tak długo, jak długo nieograniczona jest dostępność glukozy. Obecne badania nad metabolizmem komórek nowotworowych pokazują, że „efekt Warburga” to nie tylko produkcja ATP, ale znacznie więcej [1]. 95\% wyprodukowanego przez komórkę nowotworową ATP jest zużywane na podtrzymywanie funkcji życiowych, a nie na proliferację [12].

\section{Glukoza i glutamina}

Glukoza jest transportowana do komórek za pomocą umiejscowionych w błonie komórkowej transporterów glukozy (GLUT), a następnie zatrzymywana we wnętrzu komórki poprzez fosforylację do glukozo-6-fosforanu. W procesie tym uczestniczy enzym zwany heksokinazą i cząsteczka ATP [13]. Ufosforylowana glukoza podlega dalszej fosforylacji do fruktozo-1,6-bifosforanu z wykorzystaniem kolejnej cząsteczki ATP. W kolejnym etapie następuje podział na dwie cząsteczki zawierające po 3 atomy węgla, które są przekształcane do glicerolu. Glicerol służy do syntezy lipidów lub jest kolejno przekształcany do pirogronianu. Z pirogronianu powstaje acetylo-CoA, który wchodzi w dalsze reakcje w tzw. cyklu kwasów trójkarboksylowych (TCA, cykl Krebsa). Przemianom tym towarzyszy wyprodukowanie dwóch cząsteczek ATP. Sumaryczny bilans glikolizy przedstawia się następująco: zużyto dwie cząsteczki ATP - wyprodukowano 4 cząsteczki ATP. Bilans jest zatem do-
datni.W warunkach hipoksji pirogronian jest przekształcany w mleczan przez enzym - dehydrogenazę mleczanową.

Glutamina, która spośród wszystkich aminokwasów występuje w najwyższym stężeniu, służy jako substrat i donor atomów azotu dla komórek proliferujacych [14]. Glutamina wchodzi do cyklu kwasów trójkarboksylowych poprzez przekształcenie do glutaminianu, a następnie do $\alpha$-ketoglutaranu $(\alpha \mathrm{KG})$, który jest jednym z głównych produktów pośrednich TCA, jak również jest kofaktorem dla dioksygenaz $[15,16]$. Włączenie się $\alpha$-ketoglutaranu pochodzącego z przemian glutaminy w cykl kwasów trójkarboksylowych powoduje powstanie tzw. hybrydowego TCA, gdzie część cząsteczek pochodzi z przemiany glutaminy, a część z przekształcenia glukozy (ryc. 2).

W warunkach hipoksji czynnik indukowany hipoksją (HIF-1) aktywuje kinazę dehydrogenazy pirogronianu (PDK1), która z kolei hamuje dehydrogenazę pirogronianu i powstawanie acetylo-CoA z pirogronianu. W takich warunkach pirogronian przekształcany jest do mleczanu [17]. W warunkach hipoksji w komórkach proliferujących następuje przekształcanie glutaminy w cyklu kwasów trójkarboksylowych. Oznacza to, że glutamina może brać udział w metabolizmie cytrynianu i lipidów poprzez odwrócony cykl TCA lub redukcyjną karboksylację $\alpha$ KG przez dehydrogenazę izocytrynianową (IDH) [18-20]. Redukcyjna karboksylacja została odkryta i opisana po raz pierwszy w komórkach brązowej tkanki tłuszczowej, gdzie służy do syntezy lipidów. Obecnie wiadomo, że w warunkach niedotlenienia w komórkach nowotworowych redukcyjna karboksylacja jest wykorzystana do syntezy tłuszczów z glutaminy [21].

W przypadku niedoboru glukozy cykl TCA może zostać przeprogramowany, tak by był napędzany przez glutaminę, a powstające produkty będą zawierać wyłącznie atomy węgla pochodzące z glutaminy [22]. Spoczynkowe komórki T i B wykorzystują energię z utleniania kwasów tłuszczowych, jednak po stymulacji przełączają metabolizm na glikolizę i glutaminolizę [22, 23]. Zahamowanie utleniania kwasów tłuszczowych w komórkach ostrej białaczki szpikowej (AML) prowadzi do spadku ilości spoczynkowych komórek progenitorowych białaczki [24]. Badania prowadzone na komórkach AML oraz limfocytach sugerują, że utlenianie kwasów tłuszczowych jako źródła energii może być wykorzystywane w komórkach spoczynkowych o fenotypie komórek macierzystych.

\section{Dieta niskokaloryczna a ryzyko zachorowania na raka i jej wpływ na wzrost guzów}

Nadmiar kalorii powoduje otyłość, która jest przyczyną zaburzeń metabolicznych i jest często związana ze zwiększoną zachorowalnością na pewne typy nowotworów [25]. Otyłość może powodować cukrzycę w wieku dorosłym, jak również jest przyczyną podwyższonego poziomu glu- 


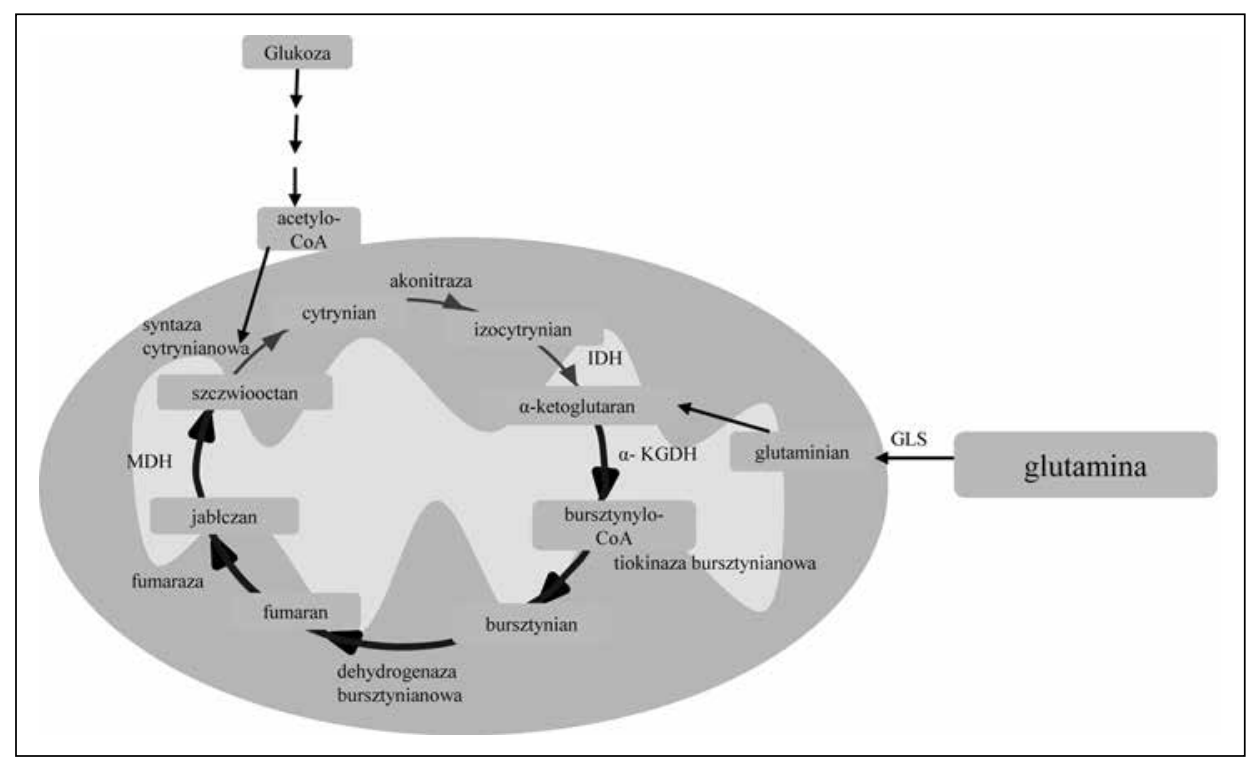

Rycina 2. Glutaminoliza jako alternatywne źródło $\alpha$ KG w cyklu kwasów trójkarboksylowych. Hybrydowy cykl TCA zaznaczony pogrubiałymi strzałkami

kozy i oporności na insulinę. Mimo że zwiększenie ryzyka zachorowania na nowotwór nie wydaje się być związane z podwyższonym poziomem glukozy krążącej we krwi, niektóre dane wskazują na to, że ograniczenie dostarczanych w pożywieniu kalorii chroni przed zachorowaniem na raka. Wciąż jednak dalecy jesteśmy od zrozumienia związku diety i/lub sposobu odżywiania z procesem kancerogenezy [26]. Jeżeli nadmiar kalorii sprzyja procesowi nowotworzenia, to - upraszczając - dieta niskokaloryczna powinna chronić przed rakiem. Badania epidemiologiczne oraz badania prowadzone na różnych modelach zwierzęcych potwierdziły, że dieta niskokaloryczna powodowała wydłużenie życia $[26,27]$.

W badaniach na modelu zwierzęcym ograniczenie spożywania kalorii hamowało powstawanie guzów prawdopodobnie poprzez obniżenie poziomu IGF-1 (insulinopodnego czynnika wzrostu) [28]. Hamowanie powstawania guzów poprzez ograniczenie ilości kalorii może być również połączone z procesami autofagii i mitofagii. Procesy te są kontrolowane przez AMPK (kinaza aktywowana AMP), która ulega aktywacji przy obniżonym statusie energetycznym, np. w stanie głodu [29]. Aktywacja AMPK zmniejsza aktywność innej kinazy, zwanej mTOR (mamalian target of rapamycin), co prowadzi do zahamowania wzrostu komórek. Farmakologiczne hamowanie aktywności mTOR prowadziło do wydłużenia czasu życia, jak również ograniczenia powstawania guzów u zwierząt. Obecnie inhibitory mTOR są wykorzystywane w leczeniu m.in. jasnokomórkowego raka nerki. Kinaza mTOR odgrywa również kluczowa rolę w regulacji komórek układu immunologicznego i w procesach zapalnych. Z powyższego wynika, że ograniczenie ilości kalorii może prowadzić do zahamowania wzrostu guza, jednak proces wzrostu nowotworów jest dużo bardziej skomplikowany i wielopłaszczyznowy. W praktyce u chorych na nowotwory często dochodzi do wyniszczenia organizmu. Okazuje się, że komórki nowotworowe doskonale radzą sobie w stanach niedoboru składników odżywczych. Przykładowo, przerzutujace komórki nowotworowe zasiedlają niszę i aby umożliwić sobie większą dostępność glukozy, powodują redukcję jej zużywania przez komórki zrębu [30].

\section{Dysfunkcje enzymów metabolicznych w nowotworach}

Mimo tego, że zmiany metaboliczne w komórce nowotworowej były już znane od wielu lat, nie było bezpośredniego połączenia pomiędzy mutacjami w genach kodujących enzymy metaboliczne a procesem nowotworzenia. Dopiero w 2006 roku King i współpracownicy zidentyfikowali mutacje w genach kodujących enzymy cyklu kwasów trójkarboksylowych, związane z rodzinnym występowaniem nowotworów [31].W szczególności stwierdzono mutacje w genie kodującym fumarazę w rodzinach dotkniętych nowotworami nerek i mięśniakowatością gładkokomórkową oraz mutacje wgeniekodującym dehydrogenazę bursztynianowąu pacjentów z guzem chromochłonnym i przyzwojakiem. Mutacje te prowadzą do zaburzenia cyklu TCA, co powoduje nadmierne nagromadzenie fumaranu lub bursztynianu. Oba te metabolity mogą hamować dioksygenazę lub hydrolazę prolilową, enzymy, które pośredniczą w degradacji białka indukowanego hipoksją HIF-1 [31]. Wzrost ilości białka HIF-1 w komórce może indukować proces kancerogenezy. Zidentyfikowane mutacje w genie dehydrogenazy izocytrynianowej (IDH) ukazały niezwykłe połączenie pomiędzy dysfunkcjami enzymu metabolicznego a procesem nowotworzenia [32, 33]. 


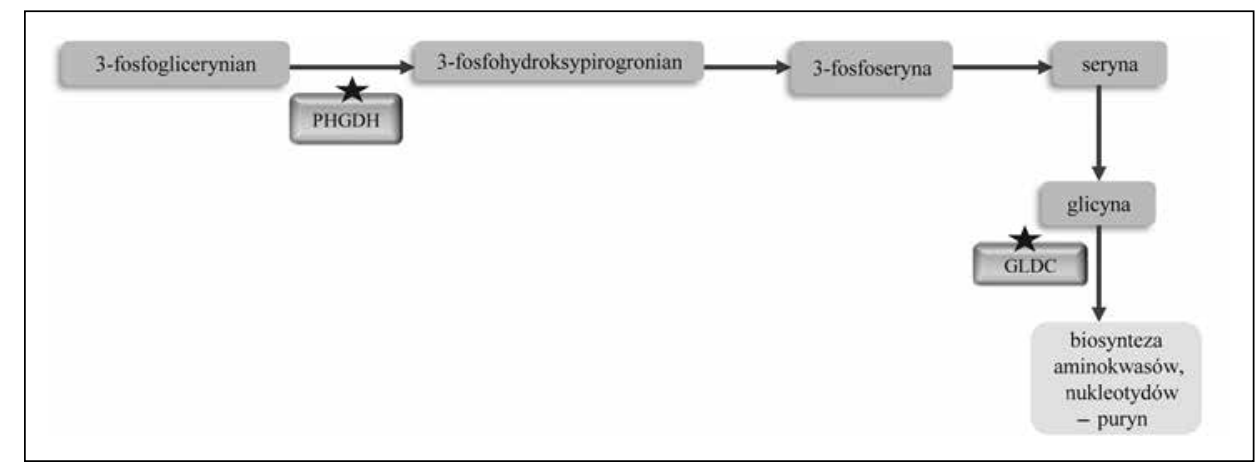

Rycina 3. Szlak biosyntezy seryny z produktu pośredniego glikolizy 3-fosfoglicerynianu. Enzymy pełniące funkcje onkogenu zaznaczono gwiazdką. PHGDH — dehydrogenza fosfoglicerynianowa, GLDC — dekarboksylaza glicyny

Mutacja w genie kodującym enzym dehydrogenazę izocytrynianową powoduje, że enzym ten nabywa nową funkcję — przekształca $\alpha$ KG do 2-hydroksyglutaranu (2-HG) zamiast izocytrynian do $\alpha$ KG [34-35]. Z kolei 2-HG hamuje dioksygenazy, enzymy które są zaangażowane w demetylację histonów i DNA [16].W przypadku glejaków status metylacji silnie korelował ze statusem IDH [36].

Poszukiwanie enzymów metabolicznych zaangażowanych w proces nowotworzenia doprowadziło do nieoczekiwanego odkrycia, że dehydrogenza fosfoglicerynianowa (PHGDH), która katalizuje pierwszy etap syntezy seryny (ryc. 3), pełni funkcje onkogenu [37, 38]. PHGDH jest zaangażowana w przemianę metabolitów pośrednich glikolizy (3-fosfoglicerynianu) do seryny, a dalej do biosyntezy nukleotydów w szlaku metabolitów jednowęglowych. Zaobserwowano amplifikacje genu PHGDH, a tym samym nadekspresję kodowanego przez ten gen enzymu w raku piersi niezależnym od estrogenu, co sugeruje, że pełni on funkcje onkogenu [38]. Innym enzymem, który może pełnić funkcję onkogenu, jest dekarboksylaza glicyny (GLDC). Enzym ten bierze udział w biosyntezie nukleotydów w szlaku metabolitów jednowęglowych (ryc. 3) [39]. Wykazano, że nadekspresja GLDC występuje w raku płuca i promuje tumorigenezę.

Kolejnym enzymem, którego nadekspresję odkryto w niedrobnokomórkowym raku płuca, raku okrężnicy i raku nerki, jest GAPDH (dehydrogenaza aldehydu fosfoglicerynowego) $[40,41]$. Enzym ten katalizuje reakcję przemiany aldehydu-3-fosfoglicerynowego do 1,3-bis-fosfoglicerynianu w procesie glikolizy.

\section{Podwójna funkcja enzymów glikolizy FBP1}

Nadekspresję lub brak niektórych enzymów katalizujących reakcje przemiany glukozy w pirogronian w szlaku glikolizy odkryto w wielu typach nowotworów. Jednym z takich enzymów jest fruktozo-1,6-bisfosfataza (FBP1) kluczowy enzym glukoneogenezy i jednocześnie enzym kontrolujący szybkość glikolizy poprzez przeciwstawne działanie do fosfofruktokinazy (PFK). FBP1 przekształca fruktozo-1,6-bisfosforan do fruktozo-6-fosforanu. Dziedziczny autosomalny recesywny niedobór FBP1 charakteryzuje się hipoglikemią i kwasicą mleczanową i często powoduje nagłą śmierć noworodków [42]. Sugeruje to, że FBP1 jest zaangażowana w kontrolę metabolizmu glukozy, a brak FBP1 powoduje wzrost wychwytu glukozy w komórkach i przyspieszoną glikolizę. Dodatkowo utratę ekspresji FBP1 spowodowaną hipermetylacją regionu promotorowego obserwuje się w raku wątroby, jelita grubego i żołądka [43, 44]. Dane te wskazują na to, że epigenetyczna regulacja locus FBP1 pełni kluczową funkcję w modulowaniu metabolizmu glukozy w komórkach nowotworowych. Utratę ekspresji FBP1 obserwowano w liniach komórkowych potrójnie ujemnego raka piersi o podtypie podobnym do mezenchymalnych komórek macierzystych, jak również w próbkach klinicznych od pacjentów. FBP1 hamuje aktywację innego enzymu glikolizy PKM2 (kinaza pirogronianowa izoforma 2). Ponowna ekspresja FBP1 w komórkach, gdzie nastąpiła jego utrata, powoduje znaczące zmniejszenie się populacji komórek nowotworowych o fenotypie komórek macierzystych, hamowanie procesu nowotworzenia, a także procentowe zmniejszenie się ilości komórek o wysokim CD44 i niskim CD24 [45]. Utratę FBP1 obserwowano również w jasnokomórkowym raku nerki, który charakteryzuje się akumulacją glikogenu i lipidów w komórkach raka. Zaobserwowano również, że FBP1 poza funkcją cytoplazmatyczną - glikolizą i glukoneogenezą — przechodzi do jądra komórkowego, gdzie blokuje aktywność transkrypcyjną czynnika indukowanego hipoksją HIF-1 [46].

\section{PKM}

Kinaza pirogronianowa (PKM) jest enzymem limitującym szybkość glikolizy - konwertuje fosfoenolopirogronian do pirogronianu. Gen PKM składa się z 12 egzonów, z których w wyniku alternatywnego składania RNA powstają dwie formy białka: PKM1 i PKM2, różniące się między sobą obecnością 9 lub 10 egzonu. 
Izoforma PKM1 występuje głównie w normalnych komórkach, natomiast PKM2 dominuje w komórkach nowotworowych [47], przy czym izoforma PKM1 jest konstytutywnie aktywna, a forma PKM2 może występować w formie nieaktywnej - dimeru i aktywnej - tetrameru. Analizy immunohistochemiczne wykazały, że izoforma PKM2 ulega ekspresji w komórkach raka jelita grubego, raku nerki oraz raku płuca. Wzrost ilości PKM2 obserwowano w surowicy u pacjentów z rakiem jelita grubego, rakiem piersi, nowotworami układu moczowego, rakiem płuca, rakiem szyjki macicy oraz nowotworami przewodu pokarmowego [48, 49]. Wysoki poziom PKM2 koreluje ze złą prognozą dla pacjentów z rakiem żołądka [50]. Nadekspresja PKM2 powoduje zwiększenie ilości Bcl-xL (białka antyapoptotycznego) w raku żołądka oraz prowadzi do zwiększenia proliferacji i potencjału migracyjnego komórek raka jelita grubego [51]. Dodatkowo wydaje się, że PKM2 bierze udział w odpowiedzi adaptacyjnej komórek na hipoksję, co jest istotne dla komórek nowotworowych. W czasie hipoksji czynnik HIF-1 $\alpha$ jest stabilizowany, co umożliwia jego dimeryzację z HIF-1 $\beta$ w jądrze komórkowym i ekspresję wielu genów zależnych od hipoksji [52]. HIF-1 aktywuje transkrypcję transporterów glukozy GLUT1 i GLUT3, heksokinazy — HK, dehydrogenazy mleczanowej A - LDHA oraz kinazy 1 dehydrogenazy pirogronianowej, która poprzez fosforylację hamuje dehydrogenazę pirogronianową (PDH) - enzym konwertujący pirogronian do acetylo-CoA [53]. PKM2 wiąże się do białka p300 i wzmacnia jego przyłączanie do elementów HRE sekwencji docelowych dla czynnika HIF-1 w DNA, przez co PKM2 działa jako koaktywator dla HIF-1, wzmacniając „, efekt Warburga" w komórkach nowotworowych [54]. Aktywność PKM2 jest regulowana przez fruktozo-1,6-bisfosforan, który poprzez wiązanie się do PKM2 aktywuje jego tetrameryzację. Natomiast związanie się ufosforylowanego peptydu wpobliżu kieszeni, do której wiąże sięfruktozo-1,6-bisfosforan, powoduje oddysocjowanie fruktozo-1,6-bisfosforanu od tetrameru PKM2, co powoduje przekształcenie do dimeru. Dimer jest mniej aktywną formą PKM2 i wydaje się być kluczowy w przeprogramowaniu metabolizmu w komórkach nowotworowych w kierunku glikolizy tlenowej [55]. Seryna również wiąże się do PKM2 i powoduje jego aktywację, natomiast niedobór seryny znacząco redukuje aktywność PKM2 [56]. Praca wykonana przez Bluemlein i współpracowników wykazała, że nadekspresja PKM2 nie jest charakterystyczna dla nowotworów, obie formy kinazy PKM1 i PKM2 występują w zdrowych tkankach. Ponadto PKM2 w zdrowych komórkach ma znacznie większą aktywność niż PKM1. Wydaje się więc, że dodatkowe postranslacyjne modyfikacje PKM2 mogą mieć znaczenie w przełączeniu metabolicznym w komórkach nowotworowych [57]. Z kolei Zhang i współpracownicy wykazali, że w komórkach nowotworowych występuje nadekspresja genu PKM, a nie przełączenie ekspresji z formy PKM1 do PKM2 [58].
Oprócz funkcji glikolitycznej PKM2, w odpowiedzi na IL-3 (interleukine-3) i sygnały apoptotyczne, przechodzi do jądra komórkowego. Jądrowa PKM2, oprócz funkcji koaktywatora dla HIF-1, wiąże się z białkiem Oct4 i wzmacnia transkrypcję regulowaną przez Oct4, ma zdolność do wiązania się $z$ ufosforylowaną formą $\beta$-kateniny i bierze udział w transaktywacji cykliny-D i c-Myc, promując tym samym proliferacje komórek i progresję nowotworu [59-61]. Ostatnie doniesienia wskazują, że dimer PKM2 także pełni funkcje jądrowe. Podsumowując, tetramer PKM2 posiada aktywność kinazy pirogronianowej i jest enzymem glikolizy w cytoplazmie, a dimer PKM2 posiada aktywność kinazy tyrozynowej i może modyfikować inne białka poprzez fosforylację, wzmacniając ich aktywność transkrypcyjną [62]. Dodatkowo, hipometylacja w obrębie intronu 1 w genie PKM koreluje z nadekspresją PKM2 w wielu typach nowotworów [63].

\section{LDH}

Dehydrogenaza mleczanowa (LDH) jest enzymem przekształcającym pirogronian do mleczanu w warunkach niedoboru tlenowego, np. w komórkach mięśni podczas zwiększonego wysiłku fizycznego. LDH ulega ekspresji we wszystkich tkankach jako jeden z pięciu izoenzymów i jest wykrywalny w surowicy krwi. Poziom LDH wzrasta w czasie uszkodzenia tkanek, nekrozy, w warunkach hipoksji, jak również podczas hemolizy i przy zawale mięśnia sercowego. Ekspresja LDH jest regulowana przez szlak PI3K/AKT/ /TORC1/HIF-1. Nadekspresja MYC również wpływa na poziom LDH [64-66]. Wzrost stężenia tego enzymu w surowicy krwi stwierdzono u pacjentów ze zdiagnozowanym chłoniakiem, mięsakiem Ewinga i glejakiem wielopostaciowym [67-69]. Podniesiony poziom LDH obserwowano również u pacjentów z zaawansowanym rakiem żołądka, gdzie koreluje on z lepszą odpowiedzią na chemioterapię, lecz krótszym czasem całkowitego przeżycia. Normalizacja podwyższonego poziomu LDH u pacjentów po chemioterapii koreluje z dobrą odpowiedzią na leczenie [70]. Podobnie poziom LDH w surowicy krwi u pacjentów z przerzutującym rakiem nerki przyjmujących inhibitory mTOR ma znaczenie prognostyczne i predykcyjne [11]. Izoenzym LDH — LDHA, oprócz lokalizacji cytoplazmatycznej, zlokalizowany jest również w jądrze komórkowym, gdzie ma zdolność do wiązania jednoniciowego DNA. Może to sugerować, że LDH odgrywa rolę w transkrypcji i/lub replikacji [71].

\section{GAPDH}

Dehydrogenaza aldehydu 3-fosfoglicerynowego (GAPDH) jest enzymem glikolizy przekształcającym aldehyd-3-fosfoglicerynowy do 1,3-bisfosfoglicerynianiu. Przez wiele lat GAPDH był uważany za gen metabolizmu podstawowego (tzw. housekeeping), czyli gen, którego ekspresja jest na stałym poziomie we wszystkich tkankach organizmu. Z tego powodu używany był w wielu publikacjach jako 


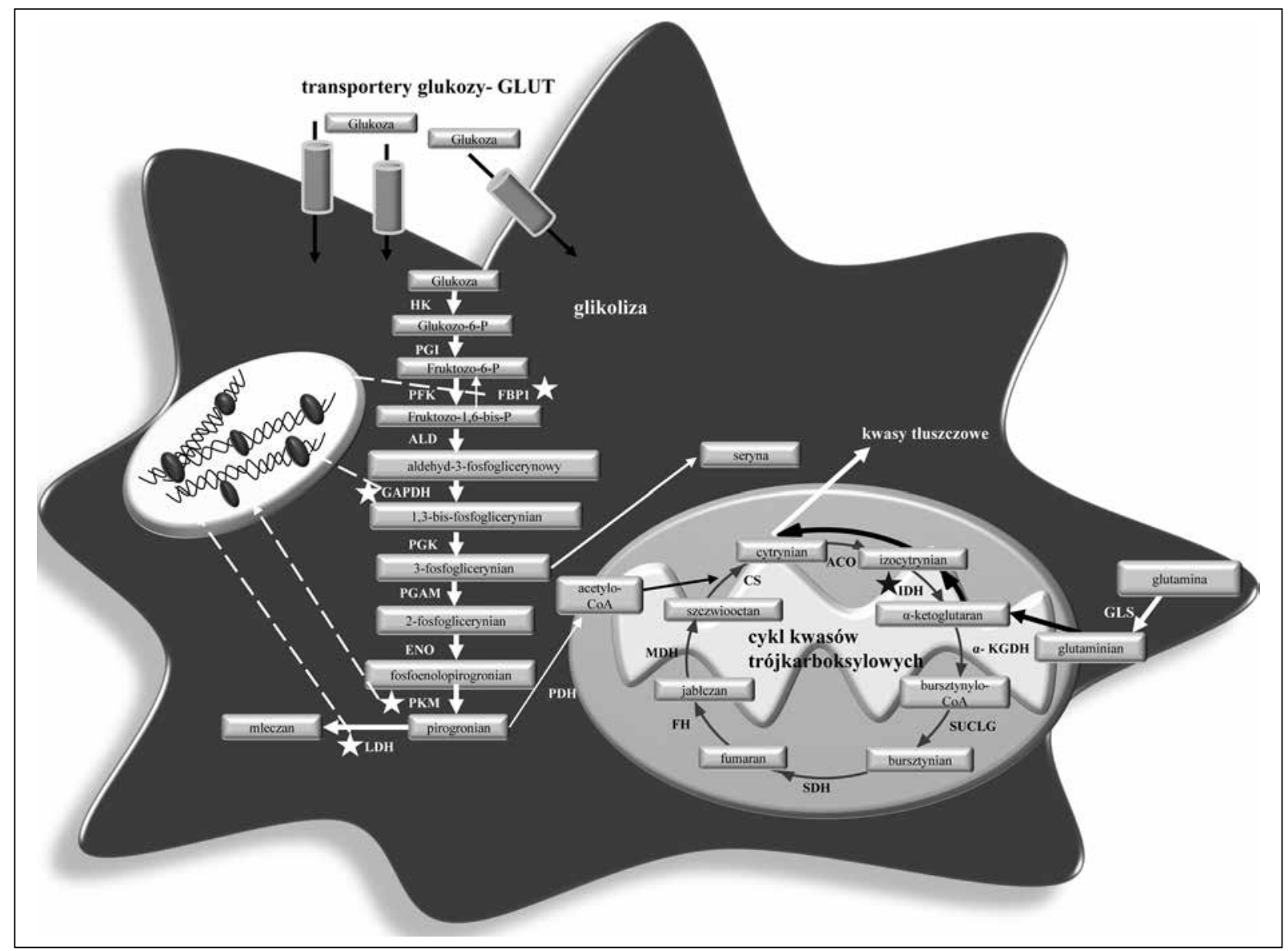

Rycina 4. Przeprogramowanie metabolizmu w komórce nowotworowej: glikoliza, cykl kwasów trójkarboksylowych i glutaminoliza. Gwiazdką zaznaczono enzymy, których zaburzenia obserwowano w komórkach nowotworowych, linią przerywaną enzymy, które przechodzą do jądra komórkowego. HK - heksokinaza, PGI — izomeraza glukozofosforanowa, PFK — fosfofruktokinaza, FBP1 — fruktoza 1,6-bisfosfataza, ALD — aldolaza, GAPDH — dehydrogenaza aldehydu 3-fosfoglicerynowego, PGK — kinaza fosfoglicerynianowa, PGAM — fosfogliceromutaza, ENO - enolaza, PKM - kinaza pirogronianowa, LDH - dehydrogenaza mleczanowa, PDH - dehydrogenaza pirogronianowa, CS - synteza cytrynianowa, ACO - akonitaza, IDH - dehydrogenaza izocytrynianowa, $\alpha$-KGDH - dehydrogenaza $\alpha$-ketoglutaranowa, SUCLG - tiokinaza bursztynianowa, SDH - dehydrogenaza bursztynianowa, FH - fumaraza, MDH — dehydrogenaza jabłczanowa, GLS — glutaminaza

gen referencyjny do analiz ekspresji genów zarówno na poziomie mRNA, jak i białka. Dane zebrane w ostatnich latach pokazują, że ekspresja GAPDH ulega rozregulowaniu w wielu typach nowotworów, jak również że enzym ten pełni inną niż glikoliza funkcję w komórce. Rola GAPDH w komórkach nowotworowych nie jest do końca wyjaśniona. Część danych wskazuje na udział GAPDH w regulacji śmierci komórkowej poprzez oddziaływanie z TERC (składnikiem RNA telomerazy), hamując aktywność telomerazy i skracanie telomerów, co powoduje starzenie się komórek nowotworowych [72]. Inne sugerują, że białko to bierze udział w progresji nowotworu i może być wykorzystane jako nowy cel terapeutyczny. GAPDH podlega ścisłym regulacjom zarówno na poziomie transkrypcyjnym, jak i potranslacyjnym. W tym ostatnim przypadku podlega takim modyfikacjom jak np. fosforylacja, ADP rybozylacja czy karbonylacja. Modyfikacje GAPDH w komórkach nowotworowych powodują, że białko to nabywa nowych funkcji niezwiązanych ze szlakiem glikolizy. Ponadto czynniki takie jak HIF-1, insulina, TP53 i inne regulują nie tylko poziom ekspresji, ale również wpływają na funkcję GAPDH [73].

\section{Podsumowanie}

Przez ostanie dziesięciolecia naukowcy, badając proces kancerogenezy, skupili swoją uwagę na zmianach w DNA takich jak: mutacje, delecje, insercje, rearanżacje, translokacje oraz na zmianach epigenetycznych. Badania te pozwoliły na opracowanie nowych metod terapii skierowanych przeciwko zmutowanym czy zmienionym produktom białkowym uszkodzonych genów. Wysokoprzepustowe techniki sekwencjonowania genomów, pomimo dostarczenia ogromnej ilości danych, nie pozwoliły jednak na jednoznaczne wyjaśnienie przyczyn procesu nowotworzenia. Dlatego naukowcy, poszukując odpowiedzi na to pytanie, powrócili do obserwacji dr. Warburga sprzed ponad 90 lat. Przeprogramowanie metabolizmu zachodzące w komór- 
kach nowotworowych (ryc. 4) dostarcza niezbędnej energii, umożliwiając ich niekontrolowany wzrost. Odkrycie nowych szlaków metabolicznych pokazało, że komórki nowotworowe sterują metabolizmem tak, aby nie zabrakło im „paliwa” do proliferacji. Poza tym dzisiaj już wiadomo, że enzymy uczestniczące w poszczególnych przemianach glukozy do pirogronianu w szlaku glikolizy (FBP1, PKM2, GAPDH, LDHA) mogą przechodzić z cytoplazmy do jądra komórkowego, gdzie pełnią zupełnie inne funkcje, niezwiązane z metabolizmem (ryc. 4). Otworzyło to nową drogę badań nad połączeniem metabolizmu z regulacją wielu innych procesów komórkowych, np. aktywacją i regulacją ekspresji genów, a co za tym idzie - kontrolą różnych procesów komórkowych.

\section{Perspektywy}

Pytanie, czy poznanie zmian metabolizmu podstawowego na poziomie komórki, a nawet organizmu, pozwoli na lepsze zrozumienie procesu kancerogenezy, ciągle pozostaje otwarte. Jeśli okaże się, że enzymy uczestniczące w podstawowych procesach metabolicznych są w istotny sposób zaangażowane w procesy nowotworzenia, to czy staną się one nowymi celami molekularnymi w terapii? Jaka jest pierwotna przyczyna powstawania nowotworów? Czy są to zmiany zachodzące w DNA, np. mutacje, które prowadzą do przeprogramowania metabolizmu? Czy odwrotnie - zmiany metaboliczne powodują zmiany na poziomie epigenetycznym, a co za tym idzie, zmiany w ekspresji różnych genów, a w konsekwencji niestabilność genetyczną? Najbliższe dziesięciolecia powinny przynieść odpowiedź na te pytania.

\section{Podziękowania}

Autorzy dziękują dr. hab. Tomaszowi Sarnowskiemu za krytyczne uwagi dotyczące manuskryptu, jak również inż. Pawłowi Ćwiekowi oraz Joannie Myślewicz za cenne uwagi. Praca finansowana z grantu numer UMO-2014/15/B/ /NZ5/03532 przyznanego przez Narodowe Centrum Nauki.

\section{Konflikt interesów: nie zgłoszono}

\section{Dr n. med. Elżbieta Sarnowska}

Zakład Onkologii Molekularnej i Translacyjnej

ul. Ronetgena 5, 02-781 Warszawa

e-mail: elasarn@coi.waw.pl

Otrzymano: 17 lipca $2015 \mathrm{r}$.

Przyjęto do druku: 26 stycznia 2016 r.

\section{Piśmiennictwo}

1. Vander Heiden MG, Cantley LC, Thompson CB. Understanding the Warburg effect: the metabolic requirements of cell proliferation. Science 2009; 324: 1029-1033.

2. Warburg O. On the origin of cancer cells. Science 1956; 123: 309-314.

3. KoppenolWH, Bounds PL, Dang CV. Otto Warburg's contributions to current concepts of cancer metabolism. Nat Rev Cancer 2011; 11:325-337.

4. Dang CV. Links between metabolism and cancer. Genes Dev 2012; 26: $877-890$.
5. Levine AJ, Puzio-Kuter AM. The control of the metabolic switch in cancers by oncogenes and tumor suppressor genes. Science 2010; 330: 1340-1344.

6. Cairns RA, Harris IS, MakTW. Regulation of cancer cell metabolism. Nat Rev Cancer 2011; 11: 85-95.

7. Carmeliet P, Dor Y, Herbert JM i wsp. Role of HIF- $1 \alpha$ in hypoxia-mediated apoptosis, cell proliferation and tumour angiogenesis. Nature 1998; 394: 485-490.

8. Bertout JA, Patel SA, Simon MC. The impact of $\mathrm{O} 2$ availability on human cancer. Nat Rev Cancer 2008; 8: 967-975.

9. Semenza GL. HIF-1: upstream and downstream of cancer metabolism. Curr Opin Genet Dev 2010; 20: 51-56.

10. Goodwin ML, Gladden LB, Nijsten MW, Jones KB. Lactate and cancer: revisiting the Warburg effect in an era of lactate shuttling. Front Nutr. 2014; 1: 27-37.

11. Armstrong AJ, George DJ, Halabi S. Serum lactate dehydrogenase predicts for overall survival benefit in patients with metastatic renal cell carcinoma treated with inhibition of mammalian target of rapamycin. J Clin Oncol 2012; 30: 3402-3407.

12. WuW, Zhao S. Metabolic changes in cancer: beyond the Warburg effect. Acta Biochim Biophys Sin (Shanghai) 2013; 45: 18-26.

13. Berg JM, Tymoczko JL, Stryer L. Biochemistry 2002 W.H. Freeman and Company, New York.

14. DeBerardinis RJ, Cheng T. Q's next: the diverse functions of glutamine in metabolism, cell biology and cancer. Oncogene 2010; 29: 313-324.

15. Chowdhury R, Yeoh KK, Tian YM i wsp. The oncometabolite 2-hydroxyglutarate inhibits histone lysine demethylases. EMBO Rep 2011; 12: 463-469.

16. Xu W, Yang H, Liuy i wsp. Oncometabolite 2-hydroxyglutarate is a competitive inhibitor of $\alpha$-ketoglutarate-dependent dioxygenases. Cancer Cell 2011; 19: 17-30.

17. Kim JW, Tchernyshyov I, Semenza GL i wsp. HIF-1-mediated expression of pyruvate dehydrogenase kinase: a metabolic switch required for cellular adaptation to hypoxia. Cell Metab 2006; 3: 177-185.

18. Wise DR, Ward PS, Shay JE i wsp. Hypoxia promotes isocitrate dehydrogenase-dependent carboxylation of $\alpha$-ketoglutarate to citrate to support cell growth and viability. Proc Natl Acad Sci 2011; 108: 19611-19616.

19. Metallo CM, Gameiro PA, Bell EL i wsp. Reductive glutamine metabolism by IDH1 mediates lipogenesis under hypoxia. Nature 2012; 481: 380-384.

20. Mullen AR, Wheaton WW, Jin ES i wsp. Reductive carboxylation supports growth in tumour cells with defective mitochondria. Nature 2011; 481: 385-388.

21. Yoo H, Antoniewicz MR, Stephanopoulos Gi wsp. Quantifying reductive carboxylation flux of glutamine to lipid in a brown adipocyte cell line. J Biol Chem 2008; 283: 20621-20627.

22. Le $A$, Lane AN, Hamaker M i wsp. Glucose-independent glutamine metabolism via TCA cycling for proliferation and survival in B cells. Cell Metab 2012; 15: 110-121.

23. Wang R, Dillon CP, Shi LZ i wsp. The transcription factor Myc controls metabolic reprogramming upon T lymphocyte activation. Immunity 2011; 35: 871-882.

24. Samudio I, Harmancey R, Fiegl M i wsp. Pharmacologic inhibition of fatty acid oxidation sensitizes human leukemia cells to apoptosis induction. J Clin Invest 2010; 120: 142-156.

25. Khandekar MJ, Cohen P, Spiegelman BM. Molecular mechanisms of cancer development in obesity. Nat Rev Cancer 2011; 11: 886-895.

26. Hursting SD, Smith SM, Lashinger LM i wsp. Calories and carcinogenesis: lessons learned from 30 years of calorie restriction research. Carcinogenesis 2010; 31: 83-89.

27. Longo VD, Fontana L. Calorie restriction and cancer prevention: metabolic and molecular mechanisms. Trends Pharmacol Sci 2010; 31: 89-98.

28. Kalaany NY, Sabatini DM. Tumours with PI3K activation are resistant to dietary restriction. Nature 2009; 458: 725-731.

29. Mihaylova MM, Shaw RJ. The AMPK signalling pathway coordinates cell growth, autophagy and metabolism. Nat Cell Bio/ 2011;13: 1016-1023.

30. Ursini-Siegel J, Siegel PM. The influence of the pre-metastatic niche on breast cancer metastasis. Cancer Lett 2015. doi:10.1016/j.canlet.2015.11.009. [Epub ahead of print].

31. King A, Selak MA, Gottlieb E. Succinate dehydrogenase and fumarate hydratase: linking mitochondrial dysfunction and cancer. Oncogene 2006; 25: 4675-4682

32. Parsons DW, Jones $\mathrm{S}$, Zhang X i wsp. An integrated genomic analysis of human glioblastoma multiforme. Science 2008; 321: 1807-1812.

33. Yan $\mathrm{H}$, Parsons DW, Jin $\mathrm{G}$ i wsp. IDH1 and IDH2 mutations in gliomas. NEngl J Med 2009; 360: 765-773. 
34. Dang L, White DW, Gross S i wsp. Cancer-associated IDH1 mutations produce 2-hydroxyglutarate. Nature 2009; 462: 739-744.

35. Gross S, Cairns RA, Minden MD i wsp. Cancer-associated metabolite 2-hydroxyglutarate accumulates in acute myelogenous leukemia with isocitrate dehydrogenase 1 and 2 mutations. J Exp Med 2010; 207: 339-344.

36. Noushmehr H,Weisenberger DJ, Diefes K i wsp. Identification of a CpG island methylator phenotype that defines a distinct subgroup of glioma. Cancer Cell 2010; 17: 510-522.

37. Locasale JW, Grassian AR, Melman T i wsp. Phosphoglycerate dehydrogenase diverts glycolytic flux and contributes to oncogenesis. Nat Genet 2011; 43: 869-874.

38. Possemato R, Marks KM, Shaul YD i wsp. Functional genomics reveal that the serine synthesis pathway is essential in breast cancer. Nature 2011; 476: 346-350.

39. Zhang WC, Shyh-Chang N, Yang H i wsp. Glycine decarboxylase activity drives non-small cell lung cancer tumor-initiating cells and tumorigenesis. Cell 2012; 148: 259-272.

40. Puzone R, Savarino G, Salvi S i wsp. Glyceraldehyde-3-phosphate dehydrogenase gene over expression correlates with poor prognosis in non small cell lung cancer patients. Mol Cancer 2013; 12: 97-104.

41. Tang Z, Yuan S, Hu Y i wsp. Over-expression of GAPDH in human colorectal carcinoma as a preferred target of 3-bromopyruvate propyl ester. J Bioenerg Biomembr 2012; 44: 117-125.

42. Emery JL, Howat AJ, Variend S, i wsp. Investigation of inborn errors of metabolism in unexpected infant deaths. Lancet 1988; 2: 29-31.

43. Chen M, Zhang J, Li N i wsp. Promoter hypermethylation mediated downregulation of FBP1 in human hepatocellular carcinoma and colon cancer. PLoS One 2011; 6: e25564.

44. Liu X, Wang $X$, Zhang J i wsp. Warburg effect revisited: an epigenetic link between glycolysis and gastric carcinogenesis. Oncogene 2010; 29: 442-450.

45. Dong C, Yuan T, Wu Y i wsp. Loss of FBP1 by Snail-mediated repression provides metabolic advantages in basal-like breast cancer. Cancer Cell 2013; 23: 316-31.

46. Li B, Qiu B, Lee DS i wsp. Fructose-1,6-bisphosphatase opposes renal carcinoma progression. Nature 2014; 513: 251-255

47. Mazurek S, Boschek CB, Hugo F i wsp. Pyruvate kinase type M2 and its role in tumor growth and spreading. Semin Cancer Biol 2005; 15 : 300-308.

48. Eigenbrodt E, Basenau D, Holthusen S i wsp. Quantification of tumor type M2 pyruvate kinase (Tu M2-PK) in human carcinomas. Anticancer Res 1997; 17: 3153-3156.

49. Luftner D, Mesterharm J, Akrivakis C i wsp. Tumor type M2 pyruvate kinase expression in advanced breast cancer. Anticancer Res 2000; 20: 5077-5082.

50. Lim JY, Yoon SO, Seol SY i wsp. Overexpression of the M2 isoform of pyruvate kinase is an adverse prognostic factor for signet ring cell gastric cancer. World J Gastroenterol 2012; 18: 4037-4043.

51. Kwon $\mathrm{OH}$, Kang TW, Kim JH i wsp. Pyruvate kinase M2 promotes the growth of gastric cancer cells via regulation of $\mathrm{BCl}-\mathrm{xL}$ expression at transcriptional level. Biochem Biophys Res Commun 2012; 423: 38-44.

52. Kaelin WG Jr, Ratcliffe PJ. Oxygen sensing by metazoans: the central role of the HIF hydroxylase pathway. Mol Cell 2008; 30: 393-402.

53. Semenza GL. Defining the role of hypoxia-inducible factor 1 in cancer biology and therapeutics. Oncogene 2010; 29: 625-634.
54. Luo W, Hu H, Chang R i wsp. Pyruvate kinase M2 is a PHD3-stimulated coactivator for hypoxia-inducible factor 1. Cell 2011; 145: 732-744.

55. Christofk HR, Vander Heiden MG, Harris MH i wsp. The M2 splice isoform of pyruvate kinase is important for cancer metabolism and tumour growth. Nature 2008; 452: 230-233.

56. Chaneton B, Hillmann $P$, Zheng $L i$ wsp. Serine is a natural ligand and allosteric activator of pyruvate kinase M2. Nature 2012; 491:458-462.

57. Bluemlein K, Grüning NM, Feichtinger RG i wsp. No evidence for a shift in pyruvate kinase PKM1 to PKM2 expression during tumorigenesis. Oncotarget 2011; 2: 393-400.

58. Zhan C, Yan L, Wang L i wsp. Isoform switch of pyruvate kinase M1 indeed occurs but not to pyruvate kinase $\mathrm{M} 2$ in human tumorigenesis. PLoS One 2015; 10: e0118663. doi: 10.1371/journal.pone.0118663. eCollection 2015.

59. Hoshino A, Hirst JA, Fujii H. Regulation of cell proliferation by interleukin-3-induced nuclear translocation of pyruvate kinase. J Biol Chem 2007; 282: 17706-17711.

60. Steták A, Veress R, Ovádi J i wsp. Nuclear translocation of the tumor marker pyruvate kinase $\mathrm{M} 2$ induces programmed cell death. Cancer Res 2007; 67: 1602-1608.

61. Lee J, Kim HK, Han YM i wsp. Pyruvate kinase isozyme type M2 (PKM2) interacts and cooperates with Oct-4 in regulating transcription. Int $J$ Biochem Cell Biol 2008; 40: 1043-1054.

62. Gao X, Wang $H$, Yang JJ i wsp. Pyruvate kinase $M 2$ regulates gene transcription by acting as a protein kinase. Mol Cell 2012; 45: 598-609.

63. Desai S, Ding M, Wang B i wsp. Tissue-specific isoform switch and DNA hypomethylation of the pyruvate kinase PKM gene in human cancers. Oncotarget 2014; 5: 8202-8210.

64. Kim JW, Dang CV: Multifaceted roles of glycolytic enzymes. Trends Biochem Sci 2005; 30: 142-150.

65. Kim JW, Dang CV. Cancer's molecular sweet tooth and the Warburg effect. Cancer Res 2006; 66: 8927-8930.

66. Majumder PK, Febbo PG, Bikoff R i wsp. mTOR inhibition reverses Akt-dependent prostate intraepithelial neoplasia through regulation of apoptotic and HIF-1-dependent pathways. Nat Med 2004; 10: 594-601.

67. Hagberg H., Siegbahn A. Prognostic value of serum lactic dehydrogenase in non-Hodgkin's lymphoma. Scand J Haematol 1983; 31: 49-65.

68. Brereton HD, Simon R, Pomeroy TC. Pretreatment serum lactate dehydrogenase predicting metastatic spread in Ewing's sarcoma. Ann Intern Med 1975; 83: 352-354.

69. Simonsson B, Grenning G, Kallander C i wsp. Prognostic value of serum lactic dehydrogenase (S-LDH) in multiple myeloma. Eur J Clin Invest 1987; 17: 336-339.

70. Lee H, Yuh Y, Kim S. Serum lactate dehydrogenase (LDH) value as a prognostic factor for the patients with advanced gastric cancer Journal of Clinical Oncology, 2009 ASCO Annual Meeting Proceedings (Post-Meeting Edition); 27.

71. Zhong $X$, Howard BD. Phosphotyrosine-containing lactate dehydrogenase is restricted to the nuclei of PC12 pheochromocytoma cells. Mol Cell Biol 1990; 10: 770-776.

72. Nicholls C, Pinto AR, Li H i wsp. Glyceraldehyde-3-phosphate dehydrogenase (GAPDH) induces cancer cell senescence by interacting with telomerase RNA component. Proc Natl Acad Sci 2012; 109: 13308-13313.

73. Zhang JY, Zhang F, Hong CQ i wsp. Critical protein GAPDH and its regulatory mechanisms in cancer cells. Cancer BiolMed 2015; 12: 10-12. 